
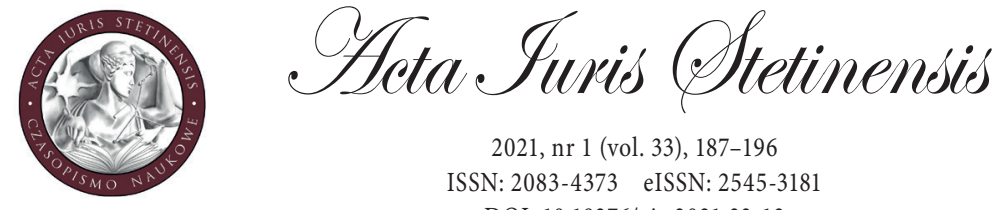

2021, nr 1 (vol. 33), 187-196

ISSN: 2083-4373 eISSN: 2545-3181

DOI: $10.18276 /$ ais.2021.33-12
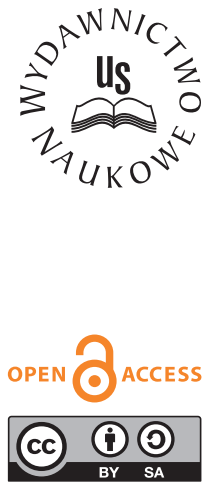

\title{
Wyrok Sądu Apelacyjnego w Szczecinie II Wydział Karny z dnia 7 stycznia 2021 r., II AKa 238/20
}

1. Regulacja art. 8 ust. 1 ustawy z dnia 23 lutego 1991 r. o uznaniu za nieważne orzeczeń wydanych wobec osób represjonowanych za działalność na rzecz niepodległego bytu Państwa Polskiego ogranicza możliwość zasądzenia odszkodowania za poniesioną szkodę i zadośćuczynienia za doznaną krzywdę wyłącznie do skutków wydania lub wykonania orzeczenia albo decyzji. W konsekwencji brakuje podstaw do zasądzenia odszkodowania i zadośćuczynienia za inne, nawet niewątpliwe, przejawy represji, ale bezpośrednio niezwiązane $\mathrm{z}$ wydaniem lub wykonaniem orzeczenia lub decyzji.

2. Zadośćuczynienie lub odszkodowanie, zgodnie z dyspozycją art. 8 ust. 1 ustawy lutowej, odnosi się do krzywdy lub szkody poniesionej przez osobę represjonowaną, a nie jej rodzinę.

3. Zadośćuczynienie oparte na treści art. 8 ust. 1 ustawy z dnia 23 lutego 1991 r. o uznaniu za nieważne orzeczeń wydanych wobec osób represjonowanych za działalność na rzecz niepodległego bytu Państwa Polskiego nie służy wynagradzaniu zasług za działalność niepodległościową, lecz ma na celu rekompensatę rzeczywiście poniesionych krzywd i szkód.

Sąd Apelacyjny w Szczecinie II Wydział Karny w składzie:

Przewodniczący: SSA Janusz Jaromin

Sędziowie: SA Piotr Brodniak, SA Maciej Żelazowski (spr.)

Protokolant: st. sekr. sądowy Anita Jagielska 
przy udziale prokuratora Prokuratury Okręgowej w Gorzowie Wlkp. Mariusza Nowaka po rozpoznaniu w dniu 7 stycznia 2021 r. sprawy P.C. o odszkodowanie z ustawy z dnia 23 lutego $1991 \mathrm{r}$. o uznaniu za nieważne orzeczeń wydanych wobec osób represjonowanych za działalność na rzecz niepodległego bytu Państwa Polskiego na skutek apelacji wniesionej przez pełnomocnika wnioskodawcy od wyroku Sądu Okręgowego w Gorzowie Wielkopolskim z dnia 23 czerwca 2020 r. sygn. akt II Ko 837/19 utrzymuje w mocy wyrok w zaskarżonej części, stwierdza, że koszty postępowania odwoławczego ponosi Skarb Państwa, zasądza od Skarbu Państwa na rzecz P.C. kwotę 240 (dwieście czterdzieści) złotych tytułem ustanowienia pełnomocnika w postępowaniu odwoławczym.

\begin{tabular}{|c|c|c|c|c|}
\hline \multicolumn{5}{|c|}{ UZASADNIENIE } \\
\hline \multicolumn{3}{|l|}{ Formularz UK 2} & $\begin{array}{l}\text { Sygnatura } \\
\text { akt }\end{array}$ & II AKa 238/20 \\
\hline \multicolumn{4}{|c|}{ Załącznik dołącza się w każdym przypadku. Podać liczbę załączników: } & 1 \\
\hline \multicolumn{4}{|c|}{ 1. CZĘŚĆ WSTĘPNA } & \\
\hline \multicolumn{5}{|c|}{ 0.11.1. Oznaczenie wyroku sqadu pierwszej instancji } \\
\hline \multicolumn{5}{|c|}{ Wyrok Sądu Okręgowego w Gorzowie Wlkp. z dnia 23 czerwca 2020 r., sygn. akt II Ko 837/19 } \\
\hline \multicolumn{5}{|c|}{ 0.11.2. Podmiot wnoszący apelację } \\
\hline \multicolumn{5}{|c|}{$\square$ oskarżyciel publiczny albo prokurator w sprawie o wydanie wyroku łącznego } \\
\hline \multicolumn{5}{|c|}{$\square$ oskarżyciel posiłkowy } \\
\hline \multicolumn{5}{|c|}{$\square$ oskarżyciel prywatny } \\
\hline \multicolumn{5}{|l|}{$\square$ obrońca } \\
\hline \multicolumn{5}{|c|}{$\square$ oskarżony albo skazany w sprawie o wydanie wyroku łącznego } \\
\hline \multicolumn{5}{|l|}{ 四 inny } \\
\hline \multicolumn{5}{|c|}{ 0.11.3. Granice zaskarżenia } \\
\hline \multicolumn{5}{|c|}{ 0.11.3.1. Kierunek i zakres zaskarżenia } \\
\hline \multirow[t]{4}{*}{$\begin{array}{l}\square \text { na korzyść } \\
\square \text { na niekorzyść }\end{array}$} & \multicolumn{4}{|l|}{$\square$ w całości } \\
\hline & ఐ w części & $\square$ & co do winy & \\
\hline & & $\square$ & co do kary & \\
\hline & & $\square$ & $\begin{array}{l}\text { co do środka kar } \\
\text { albo ustalenia }\end{array}$ & ego rozstrzygnięcia \\
\hline \multicolumn{5}{|c|}{ 0.11.3.2. Podniesione zarzuty } \\
\hline \multicolumn{5}{|c|}{ Zaznaczyć zarzuty wskazane przez strony w apelacji } \\
\hline$\nabla$ & \multicolumn{4}{|c|}{$\begin{array}{l}\text { art. } 438 \text { pkt } 1 \text { k.p.k. - obraza przepisów prawa materialnego w zakresie } \\
\text { kwalifikacji prawnej czynu przypisanego oskarżonemu }\end{array}$} \\
\hline$\square$ & \multicolumn{4}{|c|}{$\begin{array}{l}\text { art. } 438 \text { pkt la k.p.k. - obraza przepisów prawa materialnego w innym wypadku } \\
\text { niż wskazany w art. } 438 \text { pkt } 1 \text { k.p.k., chyba że pomimo błędnej podstawy prawnej } \\
\text { orzeczenie odpowiada prawu }\end{array}$} \\
\hline
\end{tabular}




\begin{tabular}{|c|c|c|c|c|c|}
\hline$\nabla$ & \multicolumn{5}{|c|}{$\begin{array}{l}\text { art. } 438 \text { pkt } 2 \text { k.p.k. - obraza przepisów postępowania, jeżeli mogła ona mieć } \\
\text { wpływ na treść orzeczenia }\end{array}$} \\
\hline$\square$ & \multicolumn{5}{|c|}{$\begin{array}{l}\text { art. } 438 \text { pkt } 3 \text { k.p.k. - błąd w ustaleniach faktycznych przyjętych za podstawę } \\
\text { orzeczenia, jeżeli mógł on mieć wpływ na treść tego orzeczenia }\end{array}$} \\
\hline$\square$ & \multicolumn{5}{|c|}{$\begin{array}{l}\text { art. } 438 \text { pkt } 4 \text { k.p.k. - rażąca niewspółmierność kary, środka karnego, nawiązki } \\
\text { lub niesłusznego zastosowania albo niezastosowania środka zabezpieczającego, } \\
\text { przepadku lub innego środka }\end{array}$} \\
\hline$\square$ & \multicolumn{5}{|c|}{ art. 439 k.p.k. } \\
\hline$\square$ & \multicolumn{5}{|c|}{ brak zarzutów } \\
\hline \multicolumn{6}{|c|}{ 0.11.4. Wnioski } \\
\hline$\square$ & \multicolumn{2}{|l|}{ Uchylenie } & \multicolumn{3}{|l|}{ Zmiana } \\
\hline \multicolumn{6}{|c|}{ 2. Ustalenie faktów w związku $z$ dowodami przeprowadzonymi przez sąd odwoławczy } \\
\hline \multicolumn{6}{|c|}{ 0.12.1. Ustalenie faktów } \\
\hline \multicolumn{6}{|c|}{ 0.12.1.1. Fakty uznane za udowodnione } \\
\hline Lp. & Oskarżony & \multicolumn{2}{|c|}{$\begin{array}{l}\text { Fakt oraz czyn, do którego fakt się } \\
\text { odnosi }\end{array}$} & Dowód & $\begin{array}{l}\text { Numer } \\
\text { karty }\end{array}$ \\
\hline \multicolumn{6}{|c|}{ 2.1.1.1 } \\
\hline \multicolumn{6}{|c|}{ 0.12.1.2. Fakty uznane za nieudowodnione } \\
\hline Lp. & Oskarżony & \multicolumn{2}{|c|}{$\begin{array}{l}\text { Fakt oraz czyn, do którego fakt się } \\
\text { odnosi }\end{array}$} & Dowód & $\begin{array}{l}\text { Numer } \\
\text { karty }\end{array}$ \\
\hline \multicolumn{6}{|c|}{ 2.1.2.1. } \\
\hline \multicolumn{6}{|c|}{ 0.12.2. Ocena dowodów } \\
\hline \multicolumn{6}{|c|}{ 0.12.2.1. Dowody będące podstawą ustalenia faktów } \\
\hline \multicolumn{2}{|c|}{ Lp. faktu z pkt 2.1.1 } & Dowód & \multicolumn{3}{|c|}{ Zwięźle o powodach uznania dowodu } \\
\hline \multicolumn{6}{|c|}{$\begin{array}{l}\text { 0.12.2.2. Dowody nieuwzględnione przy ustaleniu faktów } \\
\text { (dowody, które sq̨d uznat za niewiarygodne oraz niemające znaczenia dla ustalenia faktów) }\end{array}$} \\
\hline \multicolumn{2}{|c|}{ Lp. faktu z pkt 2.1.1 albo 2.1 .2} & Dowód & \multicolumn{3}{|c|}{ Zwięźle o powodach nieuwzględnienia dowodu } \\
\hline \multicolumn{6}{|c|}{ STANOWISKO SĄDU ODWOŁAWCZEGO WOBEC ZGŁOSZONYCH ZARZUTÓW i wniosków } \\
\hline Lp. & \multicolumn{5}{|l|}{ Zarzut } \\
\hline 3.1. & \multicolumn{3}{|c|}{$\begin{array}{l}\text { 1. Obraza przepisów postępowania, która mogła mieć wpływ } \\
\text { na treść orzeczenia, tj. art. } 3 \text { KPC } \\
\text { oraz art. } 232 \text { KPC w związku z art. } 558 \text { KPK poprzez uznanie, } \\
\text { że nie zostało wykazane ani udowodnione, że P.C.: } \\
\text { • poniósł szkodę w związku z kosztami pomocy prawnej } \\
\text { adwokata, } \\
\text { - z powodu swojej działalności początkowo nie dostał się na } \\
\text { (...). } \\
\text { 2. Obraza przepisów prawa materialnego, tj. art. } 8 \text { ust. } 1 \\
\text { ustawy z dnia } 23 \text { lutego } 1991 \text { r. o uznaniu za nieważne } \\
\text { orzeczeń wydanych wobec osób represjonowanych za } \\
\text { działalność na rzecz niepodległego bytu Państwa Polskiego } \\
\text { (dalej: ustawa lutowa), poprzez błędne przyjęcie, że działanie } \\
\text { władzy podejmowane na skutek wydania wobec P.C. wyroku } \\
\text { Sądu Rejonowego w Gorzowie Wielkopolskim Wydział } \\
\text { Rodzinny i Nieletnich z dnia } 28.12 .1982 \text { r., sygn. akt R III }\end{array}$} & $\begin{array}{l}\square \text { zasa } \\
\square \text { częś } \\
\text { zasadn } \\
\square \text { niez }\end{array}$ & $\begin{array}{l}\text { Iny } \\
\text { iowo } \\
\text { sadny }\end{array}$ \\
\hline
\end{tabular}




\begin{tabular}{|c|c|c|}
\hline 3.1. & $\begin{array}{l}\text { Nk } 42 / 82 \text { (nr prok. R III Nds 87/82), takie jak powtarzane } \\
\text { przesłuchania, namowy do współpracy, uniemożliwienie } \\
\text { podjęcia studiów oraz stres związany z prześladowaniem po } \\
\text { wydaniu wyroku, pozostają poza zakresem zastosowania } \\
\text { wskazanych wyżej norm prawnych stanowiących podstawę } \\
\text { roszczenia. } \\
\text { 3. Obraza przepisów postępowania, która mogła mieć } \\
\text { wpływ na treść orzeczenia, tj. art. } 7 \text { KPK poprzez dowolną } \\
\text { ocenę dowodów i wyciągnięcie z materiału dowodowego } \\
\text { zgromadzonego w sprawie wniosków sprzecznych } \\
\text { z zasadami prawidłowego rozumowania, doświadczenia } \\
\text { życiowego i wskazaniami wiedzy, tj. uznanie, że } \\
\text { zadośćuczynienie w kwocie } 2.000 \text { zł spełnia cel i wymogi } \\
\text { określone art. } 8 \text { ust. } 1 \text { ustawy lutowej w przypadku krzywd } \\
\text { P.C. doznanych na skutek wydania wyroku Sądu Rejonowego } \\
\text { w Gorzowie Wielkopolskim Wydział Rodzinny i Nieletnich } \\
\text { z dnia } 28.12 .1982 \text { r., sygn. akt R III Nk } 42 / 82 \text { (nr prok. } \\
\text { R III Nds } 87 / 82 \text { ), w związku z jego działalnością na rzecz } \\
\text { niepodległego bytu Państwa Polskiego. } \\
4 \text {. Obraza przepisów prawa materialnego, tj. art. } 445 \$ 11 \text { KC } \\
\text { oraz art. } 448 \text { KC, w zbiegu z art. } 8 \text { ust. } 1 \text { ustawy lutowej, } \\
\text { poprzez błędne przyjęcie, że kwota zadośćuczynienia } \\
\text { w wysokości } 2.000 \text { zł jest kwotą odpowiednią w przypadku } \\
\text { krzywd P. C. doznanych na skutek wydania wyroku Sądu } \\
\text { Rejonowego w Gorzowie Wielkopolskim Wydział Rodzinny } \\
\text { i Nieletnich z dnia } 28.12 .1982 \text { r., sygn. akt R III Nic } 42 / 82 \\
\text { (nr prok. R III Nds } 87 / 82 \text { ), w związku z jego działalnością na } \\
\text { rzecz niepodległego bytu Państwa Polskiego. }\end{array}$ & $\begin{array}{l}\square \text { zasadny } \\
\square \text { częściowo } \\
\text { zasadny } \\
\square \text { niezasadny }\end{array}$ \\
\hline & \multicolumn{2}{|c|}{$\begin{array}{l}\text { Zwięźle o powodach uznania zarzutu za zasadny, częściowo zasadny albo } \\
\text { niezasadny }\end{array}$} \\
\hline & \multicolumn{2}{|c|}{$\begin{array}{l}\text { W pierwszej kolejności stwierdzić należy, że stosownie do treści art. } 8 \text { ust. } 1 \\
\text { ustawy z dnia } 23 \text { lutego } 1991 \text { r. o uznaniu za nieważne orzeczeń wydanych wobec } \\
\text { osób represjonowanych za działalność na rzecz niepodległego bytu Państwa } \\
\text { Polskiego (Dz.U. } 2020.1820 \text { j.t.) osobie, wobec której stwierdzono nieważnó́ć } \\
\text { orzeczenia albo wydano decyzję o internowaniu w związku z wprowadzeniem } \\
\text { w dniu } 13 \text { grudnia } 1981 \text { r. w Polsce stanu wojennego, przysługuje od Skarbu } \\
\text { Państwa odszkodowanie za poniesioną szkodę i zadośćuczynienie za doznaną } \\
\text { krzywdę wynikłe z wydania lub wykonania orzeczenia albo decyzji. Oczywiste } \\
\text { zatem jest, że przedmiotem zadoścuczynienia i odszkodowania mogą być jedynie } \\
\text { te krzywdy i te szkody, które są następstwem wydania lub wykonania wyroku } \\
\text { (ewentualnie innego orzeczenia lub decyzji o internowaniu). W orzecznictwie } \\
\text { jednocześnie konsekwentnie wskazuje się, że odszkodowanie i zadośćuczynienie } \\
\text { na podstawie wymienionego wyżej przepisu przysługuje jedynie za te } \\
\text { krzywdy i szkody, które pozostają w bezpośrednim i adekwatnym związku } \\
\text { przyczynowym z wydaniem lub wykonaniem wyroku (por. postanowienie Sądu } \\
\text { Najwyższego z dnia } 24 \text { kwietnia } 2014 \text { r., VKK } 52 / 14 \text {, wyrok Sądu Apelacyjnego } \\
\text { w Warszawie z dnia } 7 \text { grudnia } 2018 \text { r., II AKa } 300 / 2018 \text {, czy wyrok Sądu } \\
\text { Apelacyjnego w Gdańsku z dnia } 3 \text { marca } 2015 \text { r., II AKa } 23 / 15 \text { ). Regulacja ta } \\
\text { zatem ogranicza możliwość zasądzenia na podstawie art. } 8 \text { ust. } 1 \text { wymienionej } \\
\text { wyżej ustawy, odszkodowania za poniesioną szkodę i zadośćuczynienia za } \\
\text { doznaną krzywdę wyłącznie do skutków wydania lub wykonania orzeczenia } \\
\text { albo decyzji. W konsekwencji brakuje podstaw do zasądzenia odszkodowania } \\
\text { i zadośćuczynienia za inne, nawet niewątpliwe, przejawy represji, ale } \\
\text { bezpośrednio niezwiązane z wydaniem lub wykonaniem orzeczenia lub decyzji. }\end{array}$} \\
\hline
\end{tabular}


Skoro zatem wobec P.C. wyrokiem Sądu Rejonowego w Gorzowie Wlkp. z dnia 28 grudnia 1982 r., syg. akt R III Nk 42/82, zastosowano środek wychowawczy w postaci dozoru kuratora sądowego, skoro wyrok ten wydany został w związku z działalnością wnioskodawcy na rzecz niepodległego bytu Państwa Polskiego i skoro postanowieniem z dnia 30 października 2019 r. stwierdzono nieważność wymienionego wyżej wyroku, to P.C. należało się odszkodowanie i zadośćuczynienie za szkody i krzywdy wynikłe z wykonania lub wydania owego wyroku. Tak też postąpił Sąd I instancji, zasądzając na rzecz wnioskodawcy zadośćuczynienie za krzywdy wynikłe z wydania wyroku (zasadnie interpretując pojęcie wydania wyroku szeroko i utożsamiając z owym wydaniem także czynności związane z zatrzymaniem i przesłuchaniem wnioskodawcy przed formalnym wydaniem w sprawie orzeczenia).

Nie zasługiwał natomiast na uwzględnienie zarzut wskazujący na dopuszczenie się przez Sąd I instancji obrazy przepisów art. 3 k.p.c., art. 232 k.p.c. w zw. $\mathrm{z}$ art. 558 k.p.k. poprzez uznanie, że wnioskodawca nie wykazał poniesienia szkody związanej z uiszczeniem kosztów pomocy prawnej adwokata. Stwierdzić bowiem należy, że Sąd I instancji nie negował ani faktu zasądzenia w wyroku Sądu Rejonowego w Gorzowie Wlkp. z dnia 28 grudnia 1982 r. od rodziców wnioskodawcy kosztów zastępstwa procesowego, ani faktu, że koszty owe zostały uiszczone. Sąd ten jedynie uznał, że owe koszty zostały zasądzone od rodziców wnioskodawcy (co wprost wynika z wymienionego wyżej wyroku pkt VI), a tym samym stanowiły szkodę, którą ponieśli rodzice wnioskodawcy, a nie on sam. Takie zaś stanowisko, wbrew wywodom apelującej, zasługiwało na pełną akceptację. Zauważyć bowiem należy, że zadośćuczynienie lub odszkodowanie, zgodnie z dyspozycją art. 8 ust. 1 ustawy lutowej, odnosi się do krzywdy lub szkody poniesionej przez osobę represjonowaną, a nie jej rodzinę (por. wyrok Sądu Apelacyjnego w Lublinie z dnia 8 listopada 2010 r., II AKa 213/10, LEX nr 785259). Wprawdzie w chwili wydania i wykonania wyroku wnioskodawca pozostawał na utrzymaniu swoich rodziców, ale fakt ten absolutnie nie mógł przesądzić o tym, że również on jest poszkodowanym w zakresie kosztów udziału w sprawie adwokata. Oczywiście oboje małżonkowie obowiązani są, każdy według swych sił oraz swych możliwości zarobkowych i majątkowych, przyczyniać się do zaspokajania potrzeb rodziny, którą przez swój związek założyli (art. 27 k.r.io.). Czym innym jest jednak przyczynianie się do zaspakajania potrzeb rodziny, a czym innym kwestia poniesienia szkody przez samego wnioskodawcę. Nie do przyjęcia jest bowiem wnioskowanie apelującej, że skoro rodzice uiścili koszty udziału w sprawie obrońcy, to niejako automatycznie zmuszeni byli z tego powodu do odmowy synowi jakichś wydatków. Nie wykazano takiego związku, a wnioskodawca w tym zakresie nie przedstawił jakichkolwiek okoliczności, zwłaszcza nie wykazał, czy i w jakim konkretnie zakresie doszło do zmniejszenia wydatków na jego osobę (nie sposób wykluczyć, że środki przeznaczone na koszty udziału w sprawie adwokata skutkowały zmniejszeniem nakładów na rodziców, a nie na syna). Brakuje zatem jakiegokolwiek przełożenia faktu zapłaty przez rodziców, rozważanych tutaj kosztów, na szkodę jaką miałby ponieść sam wnioskodawca. Zresztą sama apelująca nie do końca była przekonana co do wystąpienia wskazanego wyżej związku skoro stwierdziła, że jeżeli rodzice wnioskodawcy byli zmuszeni do wydatkowania kosztów udziału w sprawie adwokata „to z pewnością w to miejsce musieli odmówić synowi jakichś innych wydatków”. Takie twierdzenie stanowiło bowiem jedynie hipotezę, która w realiach sprawy nie znalazła potwierdzenia zwłaszcza, że i sam wnioskodawca w tym zakresie nie przedstawił jakichkolwiek konkretnych okoliczności. Nie sposób też uznać, aby zasady logiki i doświadczenia życiowego wskazywały na niejako automatyczne przełożenie wydatkowania przez rodziców jakiejś bardzo zresztą niewielkiej kwoty, na pogorszenie sytuacji dziecka, a doświadczenie życiowe raczej wskazuje, że odbyło się to kosztem potrzeb rodziców niż dziecka. Zasadnie zatem Sąd I instancji nie zasądził na rzecz wnioskodawcy kwoty 159,08 zł stanowiącej równowartość kosztów pomocy prawnej udzielonej przez adwokata i w tym zakresie wniosek oddalił. O jakiejkolwiek obrazie wymienionych wyżej przepisów nie mogło być mowy. 
Nie sposób było również podzielić poglądów apelującej jakoby we wskazanym wyżej bezpośrednim i adekwatnym związku przyczynowym $\mathrm{z}$ wydaniem lub wykonaniem wyroku Sądu Rejonowego w Gorzowie Wlkp. z dnia 28 grudnia 1982 r., syg. akt R III Nk 42/82, pozostawały krzywdy wynikłe z nakłaniania wnioskodawcy do współpracy z ówczesnymi organami bezpieczeństwa państwa, kilkakrotnych przesłuchań, czy ewentualnego utrudniania kontynuowania nauki. Wszystkie bowiem powyższe zdarzenia miały miejsce jakiś czas po wydaniu wyroku, w żaden sposób nie wynikały z jego treści i na pewno nie były następstwem jego wykonania, skoro wobec wnioskodawcy zastosowano jedynie dozór kuratora sądowego. Oczywiście nie ma podstaw do negowania prawdziwości twierdzeń wnioskodawcy co do tego, że po wydaniu wyroku był on przez okres dwóch lat około 10 razy przesłuchiwany. Jednocześnie jednak zauważyć należy, że sam wnioskodawca przyznał, iż przesłuchania owe miały miejsce wówczas, gdy zbliżała się ważna rocznica. Oczywiste zatem jest, że rozważane tutaj przesłuchania były działaniem prewencyjnym związanym z prowadzeniem wcześniej przez wnioskodawcę działalności opozycyjnej, a nie bezpośrednim następstwem wydania lub wykonania wyroku. Podobnie rzecz się miała z nakłanianiem wnioskodawcy do współpracy z organami bezpieczeństwa państwa. Trudno bowiem uznać, aby nakłanianie owo wynikało $\mathrm{z}$ wykonania lub wydania wyroku zwłaszcza, że fakt wydania tego ostatniego wręcz związek taki wykluczał. Nie sposób racjonalnie zakładać, że następstwem zastosowania środka poprawczego i to za działalność opozycyjną było nakłanianie do współpracy, która możliwość owej współpracy wręcz przekreślała. Nakłanianie owo wiązać można ewentualnie z liczeniem na wiedzę wnioskodawcy, czy nadzieją, że posiada on takie cechy, że uda się go do współpracy nakłonić (co się nie powiodło), ale na pewno nie z faktem wydania, czy wykonania wyroku poddającego wnioskodawcę dozorowi kuratora sądowego.

Na pewno też nie pozostawał w bezpośrednim i adekwatnym związku przyczynowym $\mathrm{z}$ wydaniem lub wykonaniem wyroku ewentualny fakt początkowego niedostania się pokrzywdzonego na studia. Po pierwsze bowiem, tak z zeznań wnioskodawcy, jak i z akt sprawy wynika, że P.C. faktycznie dostał się na studia i to w tym roku, w którym o przyjęcie się starał. Już zatem ten fakt w dużej części przeczył tezie o trudnościach czynionych przez władze komunistyczne w tym zakresie. O ile bowiem rzeczywiście często osoby skazywane za działalność na rzecz niepodległego bytu Państwa Polskiego $\mathrm{z}$ tego powodu miały trudności w dostaniu się na studia czy w znalezieniu pracy, ale wiązało się to z niemożliwością w ogóle rozpoczęcia studiów czy pracy, a nie z koniecznością zmiany kierunku studiów. Ponadto, nawet jeżeli wnioskodawca, jak podał, zdał wszystkie egzaminy i nie dostał się na wybrany kierunek studiów, to nie oznacza to automatycznie celowego utrudniania mu tego przez władze komunistyczne i to w efekcie wydania lub wykonania wyroku. Sytuacja wnioskodawcy w tym zakresie mogła wynikać $\mathrm{z}$ wielu czynników, takich jak duża liczba chętnych, lepsze wyniki innych osób, które również zdały egzamin itd. Po drugie, i co najważniejsze, sam wnioskodawca wiązał trudności z dostaniem się na wybrany kierunek studiów z odmową współpracy, a konkretnie z wypowiedzią funkcjonariusza, który po owej odmowie zapytał go, czy chce iść na studia i stwierdził „Jak Kuba Bogu, tak Bóg Kubie”, a nie z faktem wydania lub wykonania wyroku. Oczywiste zatem było, że ewentualne trudności w dostaniu się na studia nie były następstwem wydania lub wykonania wyroku, a niechęci wnioskodawcy do współpracy z organami bezpieczeństwa państwa. Po trzecie wnioskodawca nie był pewien wystąpienia związku pomiędzy odmową współpracy a trudnościami w dostaniu się na wybrany kierunek studiów, albowiem stwierdził „podejrzewam, że mogło to być spowodowane moją działalnością". Nie tylko zatem wnioskodawca nie był pewien związku odmowy współpracy z trudnościami w dostaniu się na wybrany kierunek studiów, ale jeszcze wyraźnie wskazywał, że związku owego upatruje w swojej działalności, a nie w wydaniu lub wykonaniu wyroku. O jakiejkolwiek obrazie art. 8 ust. 1 ustawy z dnia 23 lutego 1991 r. o uznaniu za nieważne orzeczeń wydanych wobec osób represjonowanych za działalność na rzecz Niepodległego bytu Państwa Polskiego nie mogło być mowy. 
Wreszcie, stwierdzić należy, że nie zasługiwała na uwzględnienie apelacja pełnomocnika wnioskodawcy w tym zakresie, w którym wskazywała na naruszenie przez Sąd I instancji przepisów art. 7 k.p.k., art. $445 \$ 1$ k.c. i art. 448 k.c. poprzez wadliwe ustalenie, że kwota 2000 zł zadośćuczynienia spełnia cele art. 8 ust. 1 ustawy z dnia 23 lutego 1991 r. oraz jest kwotą adekwatną do poniesionych przez wnioskodawcę krzywd. Oczywiście zgodzić się należało $\mathrm{z}$ apelującą, że zadośćuczynienie jako rekompensata za krzywdy i dolegliwości moralne oraz fizyczne winna uwzględniać rzeczywiste dolegliwości wnioskodawcy oraz odpowiadać współczesnym standardom społeczeństwa, by i krzywda została wynagrodzona i pokrzywdzony nie wzbogacił się, co byłoby moralnie niestosowne (postanowienie Sądu Apelacyjnego w Krakowie, II AKz 364/93, KZS 1994/4/44), a wysokość zadośćuczynienia, z jednej strony, powinna służyć złagodzeniu doznanej krzywdy, a z drugiej, nie może być źródłem nieuzasadnionego wzbogacenia. (postanowienie Sądu Najwyższego z dnia 22 stycznia 2015 r., III KK 252/14, LEX nr 1640256). Zauważyć jednak należy, że apelująca w ramach rozważanego tutaj zarzutu faktycznie nie kwestionowała okoliczności uwzględnionych przez Sąd Okręgowy, jako istotnych dla ustalenia wysokości zadośćuczynienia za doznaną krzywdę wynikającą z wydania i wykonania wyroku. Wskazała natomiast, że zasądzona kwota zadośćuczynienia jawi się jako nieodpowiednia bo zasądzona na zbyt niskim poziomie i na poparcie owej tezy przywołała błąd proceduralny polegający na naruszeniu art. 7 k.p.k. Ten jednak zarzut jawił się jako nieuzasadniony, albowiem Sąd I instancji, wydając orzeczenie w tym zakresie, nie naruszył reguł poprawnego rozumowania, a jego oceny nie były sprzeczne z zasadami wiedzy, logiki i doświadczenia życiowego. Miał bowiem na uwadze wszystkie te okoliczności, które miały znaczenie dla ustalenia wysokości zadośćuczynienia, a to czas zatrzymania wnioskodawcy, poziom stresu związany z izolacją od otoczenia bardzo młodej osoby, stres jaki wywołało pierwsze w życiu zatrzymanie. Z drugiej jednak strony zasadnie wskazał, co apelująca zupełnie pominęła, że wnioskodawca w czasie przesłuchania przebywał cały czas w obecności matki. Sam wnioskodawca przyznał też, że w czasie przesłuchania nie stosowano żadnych represji, jak również, że nie miał w czasie zatrzymania kontaktu $\mathrm{z}$ innymi obcymi osobami. Faktycznie zatem skala stresu związanego z zatrzymaniem i przesłuchaniem oraz poczucia krzywdy, że jest represjonowany i to w tak młodym wieku za czyn, który w demokratycznym państwie nie spotkałby się z represjami, nie była jednak aż tak duża, by uzasadniać zasądzenie zadośćuczynienia w wyższej kwocie niż uczynił to Sąd I instancji. Trzeba również dodać, że jak prawidłowo stwierdził Sąd I instancji, negatywny wpływ na psychikę wnioskodawcy, co ten sam stwierdził, miały przede wszystkim przeżycia związane z późniejszymi przesłuchaniami, namową do współpracy czy zapowiedzią, w jego odczuciu, utrudniania dostania się na studia. Jak zaś stwierdzono to już wcześniej, okoliczności te nie pozostawały w bezpośrednim i adekwatnym związku przyczynowym z wydaniem lub wykonaniem wyroku, a tym samym także ich ewentualne następstwa nie mogły mieć wpływu na ustalenie stopnia pokrzywdzenia wnioskodawcy. Trzeba również zauważyć, że zadośćuczynienie oparte na treści art. 8 ust. 1 wymienionej wyżej nie służy wynagradzaniu zasług za działalność niepodległościową, lecz ma na celu rekompensatę rzeczywiście poniesionych krzywd i szkód. Nie negując zatem podjęcia się przez wnioskodawcę działalności niepodległościowej, a w zasadzie incydentu w tym zakresie i poczucia krzywdy wynikającego ze skazania za działania, które w demokratycznym państwie nie byłyby karane, jednocześnie zauważyć należy, że zasądzona kwota zadośćuczynienia spełnia wskazane przed nią cele.

Uwzględnia bowiem rzeczywistą skalę krzywdy, uwzględnia, że wydanie i wykonanie wyroku nie wiązało się z nadmiernymi cierpieniami, jak również nie stanowi w realiach sprawy kwoty nieodpowiedniej. O obrazie wymienionych wyżej przepisów również zatem nie mogło być mowy. Żądana zaś we wniosku kwota zadośćuczynienia jawiła się jako wręcz drastycznie wygórowana i oderwana od realiów sprawy. 


\begin{tabular}{|c|c|c|}
\hline & \multicolumn{2}{|l|}{ Wniosek } \\
\hline & $\begin{array}{l}\text { o zmianę zaskarżonego wyroku poprzez zasądzenie na } \\
\text { rzecz wnioskodawcy P.C.: }\end{array}$ & \\
\hline & $\begin{array}{l}\text { 1. Dalszej kwoty w wysokości } 198.000 \text { zł, tytułem } \\
\text { zadośćuczynienia za krzywdę doznaną wskutek wydania } \\
\text { wyroku Sądu Rejonowego w Gorzowie Wielkopolskim } \\
\text { Wydział Rodzinny i Nieletnich z dnia 28.12.1982 r., sygn. } \\
\text { akt R III Nic } 42 / 82 \text { (nr prok. R III Nds 87/82), w związku } \\
\text { z działalnością na rzecz niepodległego bytu Państwa } \\
\text { Polskiego, wraz z odsetkami ustawowymi za opóźnienie od } \\
\text { dnia uprawomocnienia się wyroku do dnia zapłat. }\end{array}$ & $\begin{array}{l}\square \text { częściowo } \\
\text { zasadny } \\
\square \text { niezasadny }\end{array}$ \\
\hline & $\begin{array}{l}\text { 2. Kwoty w wysokości } 159,08 \text { zł, tytułem odszkodowania } \\
\text { za szkodę doznaną wskutek wydania wyroku Sądu } \\
\text { Rejonowego w Gorzowie Wielkopolskim Wydział Rodzinny } \\
\text { i Nieletnich z dnia 28.12.1982 r., sygn. akt R III Nk } 42 / 82 \\
\text { (nr prok. R III Nds 87/82), w związku z działalnością } \\
\text { na rzecz niepodległego bytu Państwa Polskiego, wraz } \\
\text { z odsetkami ustawowymi za opóźnienie od dnia } \\
\text { uprawomocnienia się wyroku do dnia zapłaty. }\end{array}$ & \\
\hline & $\begin{array}{l}\text { 3. Kosztów postępowania apelacyjnego, w tym kosztów } \\
\text { zastępstwa procesowego wg norm przepisanych od Skarbu } \\
\text { Państwa. }\end{array}$ & \\
\hline & \multicolumn{2}{|c|}{$\begin{array}{l}\text { Zwięźle o powodach uznania wniosku za zasadny, częściowo zasadny albo } \\
\text { niezasadny. }\end{array}$} \\
\hline & \multicolumn{2}{|l|}{ Patrz wyżej. } \\
\hline \multicolumn{3}{|c|}{ 4. OKOLICZNOŚCI PODLEGAJĄCE UWZGLĘDNIENIU Z URZĘDU } \\
\hline 4.1 & \multicolumn{2}{|l|}{ Zwięźle o powodach uwzględnienia okoliczności } \\
\hline \multicolumn{3}{|c|}{ 5. ROZSTRZYGNIĘCIE SĄDU ODWOŁAWCZEGO } \\
\hline \multicolumn{3}{|c|}{ 0.15.1. Utrzymanie w mocy wyroku sqdu pierwszej instancji } \\
\hline \multirow[t]{4}{*}{0.15 .1 .1} & \multicolumn{2}{|l|}{ Przedmiot utrzymania w mocy } \\
\hline & \multicolumn{2}{|c|}{$\begin{array}{l}\text { Wyrok Sądu Okręgowego w Gorzowie Wlkp. sygn. akt II Ko 837/19 na } \\
\text { mocy, którego zasądzono na rzecz wnioskodawcy P.C. kwotę } 2000 \text { zł tytułem } \\
\text { zadośćuczynienia za krzywdy związane z wydaniem i wykonaniem wyroku } \\
\text { Sądu Rejonowego w Gorzowie Wlkp. z dnia } 28 \text { grudnia } 1982 \text { r. sygn. akt R III } \\
\text { Nk 42/82, za działalność na rzecz niepodległego bytu Państwa Polskiego wraz } \\
\text { z ustawowymi odsetkami od dnia uprawomocnienia się wyroku oraz oddalono } \\
\text { żądanie co do kwoty 159,08 zł tytułem odszkodowania i kwoty } 198000 \text { zł tytułem } \\
\text { zadośćuczynienia. }\end{array}$} \\
\hline & \multicolumn{2}{|l|}{ Zwięźle o powodach utrzymania w mocy } \\
\hline & \multicolumn{2}{|l|}{ Patrz wyżej punkt 3.1} \\
\hline \multicolumn{3}{|c|}{ 0.15.2. Zmiana wyroku sądu pierwszej instancji w } \\
\hline \multirow[t]{2}{*}{ 0.0.15.2.1. } & \multicolumn{2}{|l|}{ Przedmiot i zakres zmiany } \\
\hline & \multicolumn{2}{|l|}{ Zwięźle o powodach zmiany } \\
\hline \multicolumn{3}{|c|}{ 0.15.3. Uchylenie wyroku sqdu pierwszej instancji } \\
\hline \multicolumn{3}{|c|}{ 0.15.3.1. Przyczyna, zakres i podstawa prawna uchylenia } \\
\hline \multirow[t]{2}{*}{ 5.3.1.1.1. } & & $\square$ art. 439 k.p.k. \\
\hline & Zwięźle o powodach uchylenia & \\
\hline
\end{tabular}




\begin{tabular}{|c|c|c|c|}
\hline \multirow[t]{2}{*}{ 5.3.1.2.1. } & \multicolumn{2}{|c|}{$\begin{array}{l}\text { Konieczność przeprowadzenia na nowo przewodu } \\
\text { w całości }\end{array}$} & $\square$ art. $437 \$ 2$ k.p.k. \\
\hline & \multicolumn{2}{|c|}{ Zwięźle o powodach uchylenia } & \\
\hline \multirow[t]{2}{*}{ 5.3.1.3.1. } & \multicolumn{2}{|c|}{ Konieczność umorzenia postępowania } & $\square$ art. $437 \$ 2$ k.p.k. \\
\hline & \multicolumn{3}{|c|}{$\begin{array}{l}\text { Zwięźle o powodach uchylenia i umorzenia ze wskazaniem szczególnej podstawy } \\
\text { prawnej umorzenia }\end{array}$} \\
\hline \multirow[t]{2}{*}{ 5.3.1.4.1. } & & & $\square$ art. $454 \S 1$ k.p.k. \\
\hline & \multicolumn{2}{|c|}{ Zwięźle o powodach uchylenia } & \\
\hline \multicolumn{4}{|c|}{ 0.15.3.2. Zapatrywania prawne i wskazania co do dalszego postępowania } \\
\hline \multicolumn{4}{|c|}{ 0.15.4. Inne rozstrzygnięcia zawarte $w$ wyroku } \\
\hline $\begin{array}{l}\text { Punkt } \\
\text { rozstrzygnięcia } \\
\text { z wyroku }\end{array}$ & \multicolumn{3}{|c|}{ Przytoczyć okoliczności } \\
\hline punkty II oraz III & \multicolumn{3}{|c|}{$\begin{array}{l}\text { Stosownie do treści art. } 13 \text { ustawy z dnia } 23 \text { lutego } 1991 \text { r. o uznaniu za nieważne } \\
\text { orzeczeń wydanych wobec osób represjonowanych za działalność na rzecz } \\
\text { niepodległego bytu Państwa Polskiego, koszty postępowania w sprawach } \\
\text { objętych ustawą, w tym z tytułu ustanowienia pełnomocnika, ponosi Skarb } \\
\text { Państwa. W tej sytuacji wskazano w punkcie II wyroku, że koszty postępowania } \\
\text { odwoławczego ponosi Skarb Państwa, a w punkcie III wyroku zasądzono na rzecz } \\
\text { P.C. kwotę } 240 \text { zł tytułem ustanowienia pełnomocnika w sprawie i jego udziału } \\
\text { w postępowaniu odwoławczym. Wysokość opłaty ustalono natomiast w oparciu } \\
\text { o treść } \$ 11 \text { ust. } 6 \text { i } \$ 15 \text { ust. } 1 \text { i } 3 \text { rozporządzenia Ministra Sprawiedliwości } \\
\text { z dnia } 22 \text { października } 2015 \text { r. w sprawie opłat za czynności radców prawnych } \\
\text { (Dz.U.2018.265 z późniejszymi zmianami) uwzględniając niezbyt duży nakład } \\
\text { pracy związany ze sporządzeniem środka odwoławczego i udziałem w rozprawie } \\
\text { odwoławczej radcy prawnego, które nie uzasadniały podwyższenia stawki } \\
\text { minimalnej. }\end{array}$} \\
\hline \multicolumn{4}{|l|}{ 6. Koszty Procesu } \\
\hline $\begin{array}{l}\text { Punkt } \\
\text { rozstrzygnięcia } \\
\text { z wyroku }\end{array}$ & \multicolumn{3}{|c|}{ Przytoczyć okoliczności } \\
\hline \multicolumn{4}{|l|}{ 7. PODPIS } \\
\hline \multicolumn{4}{|c|}{ SSA Piotr Brodniak SSA Janusz Jaromin SSA Maciej Żelazowski } \\
\hline \multicolumn{4}{|c|}{ 0.11.3. Granice zaskarżenia } \\
\hline \multicolumn{2}{|c|}{ Kolejny numer załącznika } & \multicolumn{2}{|l|}{1} \\
\hline \multicolumn{2}{|c|}{ Podmiot wnoszący apelację } & \multicolumn{2}{|c|}{ pełnomocnik wnioskodawcy P. C. } \\
\hline \multicolumn{2}{|c|}{$\begin{array}{l}\text { Rozstrzygnięcie, brak rozstrzygnięcia albo } \\
\text { ustalenie, którego dotyczy apelacja }\end{array}$} & \multicolumn{2}{|c|}{$\begin{array}{l}\text { 1. Ustalenie, że uiszczone przez rodziców } \\
\text { wnioskodawcy koszty pomocy prawnej udzielonej } \\
\text { przez adwokata nie stanowiły szkody, którą poniósł } \\
\text { sam wnioskodawca. } \\
\text { 2. Ustalenie, że przesłuchania, próba zwerbowania } \\
\text { do współpracy z organami bezpieczeństwa państwa, } \\
\text { uniemożliwienie dostania się na wybrany kierunek } \\
\text { studiów oraz stres związany z prześladowaniem po } \\
\text { wydaniu wyroku nie stanowiły następstw wydania } \\
\text { i wykonania wyroku. }\end{array}$} \\
\hline
\end{tabular}




\begin{tabular}{|c|c|c|c|}
\hline & & \multicolumn{2}{|c|}{$\begin{array}{l}\text { 3. Ustalenie, że kwota } 2000 \text { zł zadośćuczynienia } \\
\text { uwzględnia cel i wymogi określone w art. } 8 \text { ust. } 1 \\
\text { ustawy o uznaniu za nieważne orzeczeń wydanych } \\
\text { w związku z działalnością na rzecz niepodległego } \\
\text { bytu Państwa Polskiego. } \\
\text { 4. Oddalenie wniosku o zasądzenie odszkodowania } \\
\text { w kwocie } 159,08 \text { zł oraz oddalenie wniosku } \\
\text { w zakresie kwoty } 198000 \text { zł zadośćuczynienia. }\end{array}$} \\
\hline \multicolumn{4}{|c|}{ 0.11.3.1. Kierunek i zakres zaskarżenia } \\
\hline na korzyść & \multicolumn{3}{|c|}{$\square$ w całości } \\
\hline \multirow[t]{3}{*}{$\square$ na niekorzyść } & $\begin{array}{l}\square \\
\text { w części }\end{array}$ & $\square$ & co do winy \\
\hline & & $\square$ & co do kary \\
\hline & & $\square$ & $\begin{array}{l}\text { co do środka } \\
\text { karnego lub innego } \\
\text { rozstrzygnięcia albo } \\
\text { ustalenia }\end{array}$ \\
\hline \multicolumn{4}{|c|}{ 0.11.3.2. Podniesione zarzuty } \\
\hline \multicolumn{4}{|c|}{ Zaznaczyć zarzuty wskazane przez strony w apelacji } \\
\hline 四 & \multicolumn{3}{|c|}{$\begin{array}{l}\text { art. } 438 \text { pkt } 1 \text { k.p.k. - obraza przepisów prawa materialnego } \\
\text { w zakresie kwalifikacji prawnej czynu przypisanego } \\
\text { oskarżonemu }\end{array}$} \\
\hline$\square$ & \multicolumn{3}{|c|}{$\begin{array}{l}\text { art. } 438 \text { pkt la k.p.k. - obraza przepisów prawa materialnego } \\
\text { w innym wypadku niż wskazany w art. } 438 \text { pkt } 1 \text { k.p.k., chyba } \\
\text { że pomimo błędnej podstawy prawnej orzeczenie odpowiada } \\
\text { prawu }\end{array}$} \\
\hline 田 & \multicolumn{3}{|c|}{$\begin{array}{l}\text { art. } 438 \text { pkt } 2 \text { k.p.k. - obraza przepisów postępowania, jeżeli } \\
\text { mogła ona mieć wpływ na treść orzeczenia }\end{array}$} \\
\hline$\square$ & \multicolumn{3}{|c|}{$\begin{array}{l}\text { art. } 438 \text { pkt } 3 \text { k.p.k. - błąd w ustaleniach faktycznych } \\
\text { przyjętych za podstawę orzeczenia, jeżeli mógł on mieć wpływ } \\
\text { na treść tego orzeczenia }\end{array}$} \\
\hline$\square$ & \multicolumn{3}{|c|}{$\begin{array}{l}\text { art. } 438 \text { pkt } 4 \text { k.p.k. - rażąca niewspółmierność kary, środka } \\
\text { karnego, nawiązki lub niesłusznego zastosowania albo } \\
\text { niezastosowania środka zabezpieczającego, przepadku lub } \\
\text { innego środka }\end{array}$} \\
\hline$\square$ & \multicolumn{3}{|c|}{ art. 439 k.p.k. } \\
\hline$\square$ & \multicolumn{3}{|c|}{ brak zarzutów } \\
\hline \multicolumn{4}{|l|}{ 0.11.4. Wnioski } \\
\hline$\square$ & Uchylenie & $\nabla$ & Zmiana \\
\hline
\end{tabular}

